\title{
Effects of Demecolcine and Sucrose on the Incidence of Cytoplasmic Protrusions Containing Chromosomes in Pig Oocytes Matured In Vitro
}

\author{
Kazuchika MIYOSHI'), Hironori MORI'), Hideki YAMAMOTO'), Miki KISHIMOTO ${ }^{1)}$ and \\ Mitsutoshi YOSHIDA ${ }^{1)}$ \\ ${ }^{1)}$ Laboratory of Animal Reproduction, Faculty of Agriculture, Kagoshima University, Kagoshima 890-0065, Japan
}

\begin{abstract}
The present study was carried out to examine whether demecolcine and sucrose affect the formation of a cytoplasmic protrusion containing chromosomes in pig oocytes independently or in combination. In the presence of 20 $\mathrm{mM}$ sucrose, the rates of oocytes with a cytoplasmic protrusion after culture for $60 \mathrm{~min}$ with $0.2-1.0 \mu \mathrm{g} / \mathrm{ml}$ demecolcine were significantly higher than those with $0.01-0.05 \mu \mathrm{g} / \mathrm{ml}$ demecolcine. When oocytes were cultured for $15 \mathrm{~min}$ in the presence of $0.2 \mu \mathrm{g} / \mathrm{ml}$ demecolcine and $20 \mathrm{mM}$ sucrose, $35.1 \%$ of them extruded a cytoplasmic protrusion; this rate was significantly lower than those of oocytes cultured for 30-90 min. In the presence of $0.2 \mu \mathrm{g} / \mathrm{ml}$ demecolcine, significantly fewer oocytes extruded a cytoplasmic protrusion after culture for $30 \mathrm{~min}$ with $160 \mathrm{mM}$ sucrose than with $0-80 \mathrm{mM}$ sucrose. Significantly more oocytes extruded a cytoplasmic protrusion after culture for $30 \mathrm{~min}$ with $0.2 \mu \mathrm{g} / \mathrm{ml}$ demecolcine than without it, regardless of the presence or absence of $20 \mathrm{mM}$ sucrose. In $88.9-100 \%$ of the oocytes, the cytoplasmic protrusions contained chromosomes with no significant differences among the different concentrations of demecolcine and sucrose and among the different treatment times. The results of the present study show that the cytoplasmic protrusion containing chromosomes in the pig oocyte is attributable to demecolcine, but sucrose does not affect its formation.
\end{abstract}

Key words: Cytoplasmic protrusion, Demecolcine, Oocyte, Pig, Sucrose

(J. Reprod. Dev. 54: 117-121, 2008)

$S^{2}$ everal research groups have succeeded in producing cloned piglets by transfer of somatic cells into enucleated oocytes [111]. However, the efficiency of cloning, when measured as development to offspring as a proportion of embryos transferred into recipient females, is less than $1 \%$ in most of the previous reports, and widespread use of this technology in a number of animal agriculture and biomedical applications is limited. One of the important factors that affect cloning efficiency is removal of maternal chromosomes from the oocytes. Although the chromosomes of mouse and rat oocytes can be observed under an inverted microscope, the chromosomes of rabbit, sheep, goat, bovine and pig oocytes are difficult to observe due to the large lipid content in them [12]. In these species, therefore, the position of the chromosomes is usually indirectly determined by the location of the first polar body or directly observed under ultraviolet light after staining the oocytes with a DNA-specific dye such as Hoechst 33342. However, polar bodies often migrate from their place of origin and do not always remain in proximity to chromosomes [13-16]. Meanwhile, DNA dyes and ultraviolet light exposure have been reported to have detrimental effects on oocytes and their developmental potential [15, 17, 18].

Recently, Yin et al. [12] reported that brief treatment of in vitromatured pig oocytes with demecolcine, a microtubule disrupter, and sucrose induces a cytoplasmic protrusion containing chromosomes into the perivitelline space that can be easily removed by aspiration. This chemically assisted enucleation of oocytes has

Accepted for publication: December 21, 2007

Published online: January 30, 2008

Correspondence: K. Miyoshi (e-mail: kmiyoshi@agri.kagoshima-u.ac.jp) been applied to the production of cloned pigs [12, 19] and miniature pigs [20] derived from somatic cells. In the presence of sucrose, the concentration of demecolcine affects the cytoplasmic protrusion of pig oocytes [19]. On the other hand, it has been reported that hypertonic treatment with sucrose induces formation of a protrusion around the chromosome and spindle area in mouse [21, 22] and bovine [23] oocytes, suggesting that the hypertonicity induced by sucrose might also be essential for the cytoplasmic protrusion in pig oocytes [19]. However, there are no reports that have tested this hypothesis. Clarification of the roles of demecolcine and sucrose in the formation of a cytoplasmic protrusion is important for optimization of chemically assisted enucleation of pig oocytes.

Therefore, the present study examined whether demecolcine and sucrose affect formation of a cytoplasmic protrusion containing chromosomes in pig oocytes independently or in combination.

\section{Materials and Methods}

\section{In vitro maturation of oocytes}

Ovaries were collected from prepubertal gilts at a local slaughterhouse and transported to the laboratory in saline at $35 \mathrm{C}$. The follicular contents were recovered by aspiration from follicles (2-5 $\mathrm{mm}$ in diameter) using an 18-gauge needle (Terumo, Tokyo, Japan) and a 5-ml disposable syringe (Nipro, Osaka, Japan). The cumulus-oocyte complexes (COCs) were gathered from the follicular contents and washed twice with HEPES-buffered Tyrode-lactatepyruvate-polyvinyl alcohol (PVA) and the maturation medium, respectively. Only COCs possessing a compact cumulus mass and evenly granulated ooplasm were selected. COCs in groups of 20 
Table 1. The incidence of cytoplasmic protrusions in pig oocytes treated with different concentrations of demecolcine

\begin{tabular}{cccc}
\hline $\begin{array}{c}\text { Concentration } \\
\text { of demecolcine } \\
(\mu \mathrm{g} / \mathrm{ml})\end{array}$ & $\begin{array}{c}\text { No. of } \\
\text { oocytes } \\
\text { examined }\end{array}$ & $\begin{array}{c}\text { No. }(\%)^{\mathrm{b}} \text { of oocytes } \\
\text { with a cytoplasmic } \\
\text { protrusion }\end{array}$ & $\begin{array}{c}\text { No. (\%) })^{\mathrm{c}} \text { of oocytes with } \\
\text { a cytoplasmic protrusion } \\
\text { containing chromosomes }\end{array}$ \\
\hline 0.01 & 90 & $31(34.4)^{\mathrm{d}}$ & $30(96.8)$ \\
0.05 & 90 & $38(42.2)^{\mathrm{d}, \mathrm{e}}$ & $38(100)$ \\
0.1 & 89 & $45(50.6)^{\mathrm{d}, \mathrm{e}, \mathrm{f}}$ & $45(100)$ \\
0.2 & 100 & $68(68.0)^{\mathrm{f}}$ & $68(100)$ \\
0.5 & 75 & $47(62.7)^{\mathrm{f}}$ & $67(100)$ \\
1.0 & 105 & $69(65.7)^{\mathrm{f}}$ & $43(100)$ \\
1.5 & 77 & $43(55.8)^{\mathrm{e}, \mathrm{f}}$ & $41(100)$ \\
2.0 & 77 & $41(53.2)^{\mathrm{d}, \mathrm{e}, \mathrm{f}}$ & \\
\hline
\end{tabular}

aocytes were cultured for $60 \mathrm{~min}$ in the presence of $20 \mathrm{mM}$ sucrose. The osmolarity of each medium was $314 \mathrm{mOsm}$.

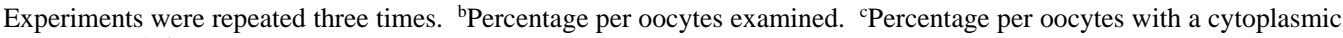
protrusion. ${ }^{\text {de, }, f}$ Values with different superscripts are significantly different $(\mathrm{P}<0.05)$.

30 were transferred to a droplet of the maturation medium (200 $\mu \mathrm{l})$ under paraffin oil (Nacalai Tesque, Kyoto, Japan) in a 35-mm polystyrene dish (Becton Dickinson, Franklin Lakes, NJ, USA) and cultured at $38.5 \mathrm{C}$ in an atmosphere of $5 \% \mathrm{CO}_{2}$ in air. The maturation medium consisted of 90\% (v:v) TCM-199 with Earle's salts (Gibco BRL, Grand Island, NY, USA) supplemented with 0.91 mM sodium pyruvate (Sigma-Aldrich Chemical, St. Louis, MO, USA), 3.05 mM D-glucose (Wako Pure Chemical, Osaka, Japan), $0.57 \mathrm{mM}$ cysteine hydrochloride hydrate (Sigma), $10 \mathrm{ng} / \mathrm{ml}$ epidermal growth factor (Sigma), 10 IU/ml eCG (Teikoku-Zoki, Tokyo, Japan), $10 \mathrm{IU} / \mathrm{ml}$ hCG (Teikoku-Zoki), $100 \mu \mathrm{g} / \mathrm{ml}$ amikacin sulfate (Meiji Seika, Tokyo, Japan), 0.1\% (w:v) PVA and 10\% (v:v) pig follicular fluid. After 38-42 h of culture, cumulus cells were removed by pipetting with $0.1 \%$ (w:v) hyaluronidase (Sigma). Oocytes with a polar body were selected for the experiments.

\section{Induction of cytoplasmic protrusions}

HEPES-buffered TCM-199 (Gibco) supplemented with $0.4 \%$ (w:v) bovine serum albumin (HEPES-TCM-BSA) was used as the basic medium. In vitro-matured and denuded oocytes were cultured in $100 \mu \mathrm{l}$ of HEPES-TCM-BSA supplemented with demecolcine (Sigma) and sucrose at various concentrations for various times under $5 \% \mathrm{CO}_{2}, 5 \% \mathrm{O}_{2}$ and $90 \% \mathrm{~N}_{2}$ at $38.5 \mathrm{C}$. For the last $5 \mathrm{~min}$ of each culture, $5 \mu \mathrm{g} / \mathrm{ml}$ Hoechst 33342 (Sigma) was added to the medium. After culture, the oocytes were examined for the presence of a cytoplasmic protrusion under an inverted microscope. Oocytes with a cytoplasmic protrusion were examined to determine the location of the chromosomes under ultraviolet light.

\section{Experimental designs}

In experiment 1 , the effects of the demecolcine concentration on the incidence of cytoplasmic protrusions were examined by culturing oocytes in HEPES-TCM-BSA supplemented with $20 \mathrm{mM}$ sucrose [20] and $0.01,0.05,0.1,0.2,0.5,1.0,1.5$ or $2.0 \mu \mathrm{g} / \mathrm{ml}$ demecolcine for $60 \mathrm{~min}$. The osmolarity of each medium was 314 mOsm when measured using a vapor pressure osmometer (Wescor, Logan, UT, USA).

In experiment 2, the effects of the treatment times of demecolcine and sucrose on the incidence of cytoplasmic protrusions were examined. Oocytes were cultured in HEPES-TCM-BSA supplemented with $0.2 \mu \mathrm{g} / \mathrm{ml}$ demecolcine and $20 \mathrm{mM}$ sucrose for 15,30 , 60 or 90 min. The measured osmolarity of the medium was 314 mOsm.

In experiment 3 , to examine the effects of the sucrose concentration on the incidence of cytoplasmic protrusions, oocytes were cultured in HEPES-TCM-BSA supplemented with $0.2 \mu \mathrm{g} / \mathrm{ml}$ demecolcine and $0,10,20,40,80$ or $160 \mathrm{mM}$ sucrose for $30 \mathrm{~min}$. The measured osmolarities of the medium containing $0,10,20,40$, 80 and $160 \mathrm{mM}$ sucrose were 292, 301, 314, 336, 372 and 454 mOsm, respectively.

In experiment 4 , the effects of the presence or absence of demecolcine with or without sucrose on the incidence of cytoplasmic protrusions were examined by culturing oocytes in HEPES-TCMBSA supplemented with $0.2 \mu \mathrm{g} / \mathrm{ml}$ demecolcine and/or $20 \mathrm{mM}$ sucrose for $30 \mathrm{~min}$. Regardless of the presence or absence of demecolcine, the measured osmolarities of the medium with and without sucrose were 314 and 292 mOsm, respectively.

\section{Statistical analysis}

All percentage data were subjected to an arcsin transformation in each replicate. The transformed values were analyzed by one-way (experiments 1, 2 and 3) or two-way (experiment 4) ANOVA followed by Fisher's protected least significant difference test. A probability of $\mathrm{P}<0.05$ was considered statistically significant.

\section{Results}

As shown in Table 1, the rates of oocytes with a cytoplasmic protrusion (Fig. 1a) at $0.2-1.0 \mu \mathrm{g} / \mathrm{ml}$ demecolcine (62.7-68.0\%) were significantly $(\mathrm{P}<0.05)$ higher than those at $0.01-0.05 \mu \mathrm{g} / \mathrm{ml}$ demecolcine (34.4-42.2\%), although these rates were not different from those at 0.1 and $1.5-2.0 \mu \mathrm{g} / \mathrm{ml}$ demecolcine (50.6-55.8\%). In $96.8-100 \%$ of the oocytes, the cytoplasmic protrusions contained chromosomes (Fig. 1b), with no significant differences among the different concentrations of demecolcine.

When oocytes were cultured for 15 min with demecolcine and sucrose, $35.1 \%$ of them extruded a cytoplasmic protrusion; this rate was significantly $(\mathrm{P}<0.05)$ lower than those $(55.6-63.9 \%)$ of 

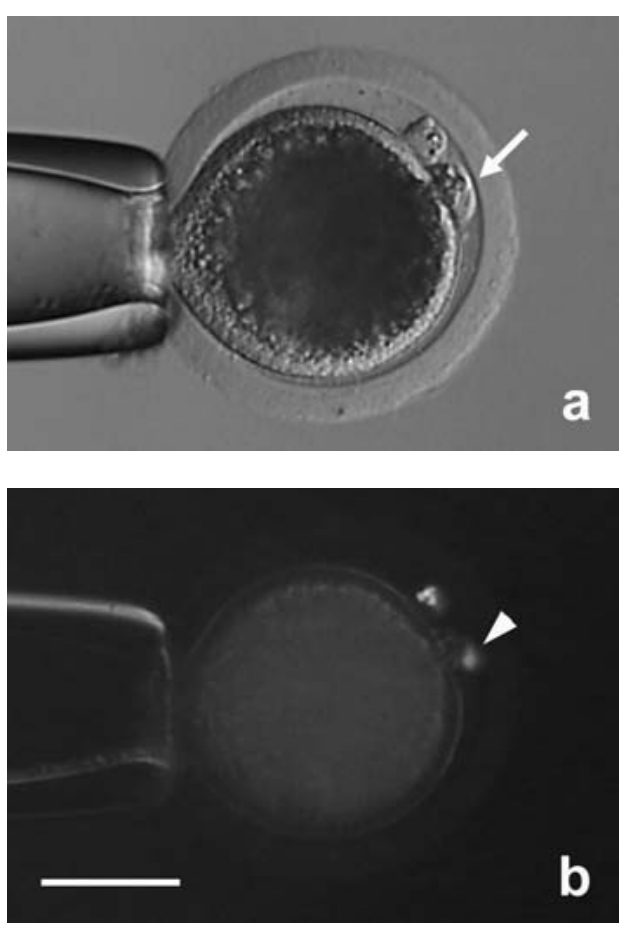

Fig. 1. A pig oocyte treated with $0.2 \mu \mathrm{g} / \mathrm{ml}$ demecolcine and $20 \mathrm{mM}$ sucrose for $60 \mathrm{~min}$ under normal (a) and ultraviolet (b) light. The oocyte extruded a cytoplasmic protrusion (arrow) containing chromosomes (arrowhead). Scale bar $=50 \mu \mathrm{m}$. oocytes cultured for 30, 60 or 90 min (Table 2). The cytoplasmic protrusions of all of the oocytes $(100 \%)$ contained chromosomes, regardless of the different treatment times.

As shown in Table 3 , significantly $(\mathrm{P}<0.05)$ fewer oocytes extruded a cytoplasmic protrusion after culture with $160 \mathrm{mM}$ sucrose (16.1\%) than with $0-80 \mathrm{mM}$ sucrose (61.0-73.4\%). There were no significant differences in the rates (61.0-73.4\%) among the oocytes cultured with $0-80 \mathrm{mM}$ sucrose. In the absence of sucrose, however, cytoplasmic protrusions were difficult to observe because of the small perivitelline spaces of the oocytes (Fig. 2). In $88.9-100 \%$ of the oocytes, the cytoplasmic protrusions contained chromosomes, with no significant differences among the different concentrations of sucrose.

Significantly $(\mathrm{P}<0.01)$ more oocytes extruded a cytoplasmic protrusion after culture with demecolcine (50.0-54.7\%) than without it (3.3-6.7\%), regardless of the presence or absence of sucrose (Table 4). The cytoplasmic protrusions contained chromosomes in all of the oocytes (100\%), regardless of the presence or absence of demecolcine with or without sucrose.

\section{Discussion}

The results of the present study show that the cytoplasmic protrusion containing chromosomes in the pig oocyte is attributable to demecolcine and that sucrose does not affect its formation.

The mechanisms involved in formation of a cytoplasmic protrusion in oocytes treated with demecolcine and/or sucrose are unclear. The cytoplasmic protrusion containing chromosomes in the mouse oocyte is considered to be induced by hypertonicity, the

Table 2. The incidence of cytoplasmic protrusions in pig oocytes treated with demecolcine and sucrose for different periods of time $^{\mathrm{a}}$

\begin{tabular}{ccccc}
\hline $\begin{array}{c}\text { Treatment } \\
\text { time } \\
(\mathrm{min})\end{array}$ & $\begin{array}{c}\text { No. of } \\
\text { trials }\end{array}$ & $\begin{array}{c}\text { No. of } \\
\text { oocytes } \\
\text { examined }\end{array}$ & $\begin{array}{c}\text { No. }(\%)^{\mathrm{b}} \text { of oocytes } \\
\text { with a cytoplasmic } \\
\text { protrusion }\end{array}$ & $\begin{array}{c}\text { No. (\%) })^{\mathrm{c}} \text { of oocytes with } \\
\text { a cytoplasmic protrusion } \\
\text { containing chromosomes }\end{array}$ \\
\hline 15 & 8 & 168 & $59(35.1)^{\mathrm{d}}$ & $59(100)$ \\
30 & 8 & 160 & $89(55.6)^{\mathrm{e}}$ & $89(100)$ \\
60 & 8 & 155 & $99(63.9)^{\mathrm{e}}$ & $99(100)$ \\
90 & 7 & 103 & $59(57.3)^{\mathrm{e}}$ & $59(100)$ \\
\hline
\end{tabular}

aocytes were cultured in the presence of $0.2 \mu \mathrm{g} / \mathrm{ml}$ demecolcine and $20 \mathrm{mM}$ sucrose. The osmolarity of the medium was 314 mOsm. ${ }^{b}$ Percentage per oocytes examined. 'Percentage per oocytes with a cytoplasmic protrusion. ${ }^{\mathrm{d}, \mathrm{e}}$ Values with different superscripts are significantly different $(\mathrm{P}<0.05)$.

Table 3. The incidence of cytoplasmic protrusions in pig oocytes treated with different concentrations of sucrose $\mathrm{a}^{\mathrm{a}}$

\begin{tabular}{cccccc}
\hline $\begin{array}{c}\text { Concentration } \\
\text { of sucrose } \\
(\mathrm{mM})\end{array}$ & $\begin{array}{c}\text { Osmolarity } \\
\text { (mOsm) }\end{array}$ & $\begin{array}{c}\text { No. of } \\
\text { trials }\end{array}$ & $\begin{array}{c}\text { No. of } \\
\text { oocytes } \\
\text { examined }\end{array}$ & $\begin{array}{c}\text { No. }(\%)^{\mathrm{b}} \text { of oocytes } \\
\text { with a cytoplasmic } \\
\text { protrusion }\end{array}$ & $\begin{array}{c}\text { No. }(\%)^{\mathrm{c}} \text { of oocytes with } \\
\text { a cytoplasmic protrusion } \\
\text { containing chromosomes }\end{array}$ \\
\hline 0 & 292 & 3 & 60 & $39(65.0)^{\mathrm{d}}$ & $39(100)$ \\
10 & 301 & 3 & 60 & $40(66.7)^{\mathrm{d}}$ & $40(100)$ \\
20 & 314 & 4 & 94 & $69(73.4)^{\mathrm{d}}$ & $69(100)$ \\
40 & 336 & 3 & 59 & $36(61.0)^{\mathrm{d}}$ & $36(100)$ \\
80 & 372 & 4 & 78 & $48(61.5)^{\mathrm{d}}$ & $78(100)$ \\
160 & 454 & 3 & 56 & $9(16.1)^{\mathrm{e}}$ & $8(88.9)$ \\
\hline
\end{tabular}

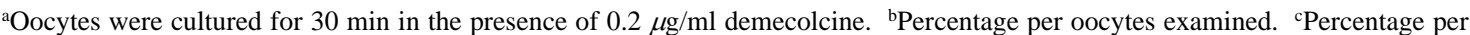
oocytes with a cytoplasmic protrusion. d,e Values with different superscripts are significantly different $(\mathrm{P}<0.05)$. 


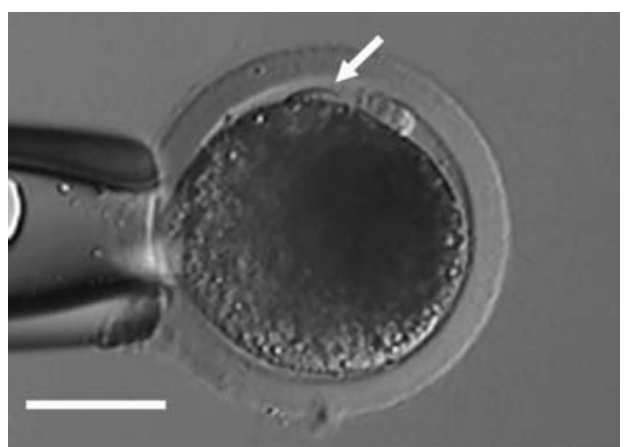

Fig. 2. A pig oocyte extruded a cytoplasmic protrusion (arrow) after culture for $30 \mathrm{~min}$ with $0.2 \mu \mathrm{g} / \mathrm{ml}$ demecolcine. Scale bar $=50 \mu \mathrm{m}$.

common role for sucrose in cryopreservation [24-27], because hypertonic solutions containing high concentrations of other sugars, such as maltose, trehalose, sorbitol, mannitol and glucose, or $\mathrm{NaCl}$ can also induce the same phenomenon [22]. Sucrose, which is unable to permeate through the plasma membrane, induces water molecules to move out of oocytes and, thus, effectively causes them to shrink. Liu et al. [22] estimated that shrinkage of mouse oocytes induced by hypertonicity of more than 470 mOsm brings the spindle-chromosome complex, where both poles of the spindle are anchored to the cortex by microtubule and non-microtubule elements, closer to the plasma membrane. The chromosomes are then attached to the plasma membrane, and cytoplasmic protrusions are formed due to bulging of the rigid spindle-chromosome complex through the plasma membrane. The same protocol could be applied to bovine oocytes, although hypertonicity of more than 671 mOsm, adjusted by adding more than $300 \mathrm{mM}$ sucrose, is needed to induce a cytoplasmic protrusion containing chromosomes in them [23]. In contrast, this protocol might not be useful for pig oocytes; although $60.0 \%$ of the oocytes extruded a cytoplasmic protrusion after culture in HEPES-TCM-BSA with osmolarity adjusted to 608 mOsm by addition of $300 \mathrm{mM}$ sucrose, the protrusions contained chromosomes in only $33.3 \%$ of the oocytes in our preliminary experiment (unpublished data).

On the other hand, cytoplasmic protrusions containing chromosomes could be induced in pig oocytes in medium with the osmolarity adjusted to $337 \mathrm{mOsm}$ by addition of $50 \mathrm{mM}$ sucrose only if demecolcine was present $[12,19]$. The mechanisms of this phenomenon have been explained as follows [19]. The meiotic spindle of oocytes treated with demecolcine is disorganized, and the chromosomes become condensed. The condensed chromosomes become closer, but are not attached to the plasma membrane due to the low concentration of sucrose. However, the condensed chromosomes anchored to the actin-rich domain might provide a more rigid structure for the oocyte cortex. Although we agree with this hypothesis, the movement of condensed chromosomes to the plasma membrane might not be attributable to the shrinkage of oocytes induced by sucrose because cytoplasmic protrusions containing chromosomes were observed even when pig oocytes were treated with demecolcine in isotonic medium without sucrose (292 mOsm). The condensation of maternal chromosomes by microtubule disrupters, such as demecolcine, would be related to their movement to the plasma membrane. In the absence of demecolcine, a high concentration of sucrose is essential for movement of maternal chromosomes to the plasma membrane because the movement is only attributable to shrinkage of the oocytes. In the presence of demecolcine, however, chromosomes might spontaneously move to the plasma membrane after condensation, and in this case, addition of sucrose might not be needed. In contrast to the observations of Liu et al. [23] showing that cytoplasmic protrusions containing chromosomes were observed in bovine oocytes in medium with the osmolarity adjusted to 671-1587 mOsm by addition of 300-900 mM sucrose, Tani et al. [28] reported that the same phenomenon can be induced in isotonic medium containing demecolcine. Furthermore, shrinkage of oocytes induced by sucrose might prevent movement of chromosomes condensed by demecolcine because in the presence of demecolcine, the rate of oocytes with a cytoplasmic protrusion in medium with the osmolarity adjusted to $454 \mathrm{mOsm}$ by addition of $160 \mathrm{mM}$ sucrose is significantly lower than that in isotonic medium without sucrose.

It has been reported that the basic medium is not involved in induction of a cytoplasmic protrusion containing chromosomes in mouse oocytes using sucrose [22]. However, the effects of the basic medium on the phenomenon induced by demecolcine or in other species are unclear. Under our experimental conditions, the adequate concentration and treatment time of demecolcine for inducing a cytoplasmic protrusion containing chromosomes in pig oocytes were $0.2-1.0 \mu \mathrm{g} / \mathrm{ml}$ and $30-90 \mathrm{~min}$, respectively. These results are in agreement with those of a previous report [19] in which high rates of pig oocytes with a cytoplasmic protrusion con-

Table 4. The incidence of cytoplasmic protrusions in pig oocytes treated with demecolcine and/or sucrose ${ }^{\mathrm{a}}$

\begin{tabular}{|c|c|c|c|c|c|}
\hline \multicolumn{2}{|c|}{ Supplement } & \multirow{2}{*}{$\begin{array}{c}\text { Osmolarity } \\
\text { (mOsm) }\end{array}$} & \multirow{2}{*}{$\begin{array}{c}\text { No. of } \\
\text { oocytes } \\
\text { examined }\end{array}$} & \multirow{2}{*}{$\begin{array}{l}\text { No. }(\%)^{\mathrm{b}} \text { of oocytes } \\
\text { with a cytoplasmic } \\
\text { protrusion }\end{array}$} & \multirow{2}{*}{$\begin{array}{l}\text { No. }(\%)^{\mathrm{c}} \text { of oocytes with } \\
\text { a cytoplasmic protrusion } \\
\text { containing chromosomes }\end{array}$} \\
\hline Demecolcine & Sucrose & & & & \\
\hline - & - & 292 & 60 & $4(6.7)^{\mathrm{d}}$ & $4(100)$ \\
\hline+ & - & 292 & 56 & $28(50.0)^{\mathrm{e}}$ & 28 (100) \\
\hline- & + & 314 & 60 & $2(3.3)^{\mathrm{d}}$ & $2(100)$ \\
\hline+ & + & 314 & 86 & $47(54.7)^{\mathrm{e}}$ & 47 (100) \\
\hline
\end{tabular}

${ }^{a}$ Oocytes were cultured for $30 \mathrm{~min}$ in the presence of $0.2 \mu \mathrm{g} / \mathrm{ml}$ demecolcine and/or $20 \mathrm{mM}$ sucrose. Experiments were repeated three

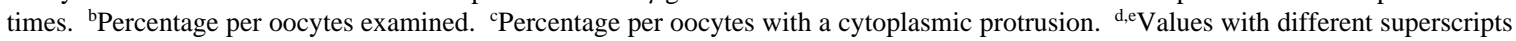
are significantly different $(\mathrm{P}<0.01)$. 
taining chromosomes were obtained after culture for 30-60 min with $0.1-0.4 \mu \mathrm{g} / \mathrm{ml}$ demecolcine. HEPES-TCM-BSA and NCSU 37 [29] were used as the basic medium for induction of cytoplasmic protrusions in the present study and the previous report, respectively. Therefore, the basic medium is probably not an important factor for induction of a cytoplasmic protrusion containing chromosomes in pig oocytes using demecolcine.

The results of the present study indicated clearly that sucrose is not needed to induce a cytoplasmic protrusion containing chromosomes in pig oocytes in the presence of demecolcine. However, cytoplasmic protrusions are easier to observe with the addition of sucrose because it enlarges the perivitelline space in oocytes [12, 19]. Therefore, the presence or absence of sucrose would affect the enucleation efficiency of oocytes after treatment with demecolcine. On the other hand, it is possible that sucrose treatment has detrimental effects on the developmental potential of cloned embryos, although normal cloned pigs and miniature pigs have been produced that were derived from oocytes whose maternal chromosomes were removed after treatment with demecolcine and sucrose [12, 19, 20]. Therefore, further studies are required to determine whether sucrose is needed for chemically assisted enucleation of pig oocytes.

\section{Acknowledgements}

We express gratitude to the staff of the Kagoshima City Meat Inspection Office and Meat Center Kagoshima (Kagoshima, Japan) for supplying pig ovaries. The present study was supported by Grants-in-Aid for Scientific Research (No. 16688008, 17100007 and 19580328) from Japan Society for the Promotion of Science.

\section{References}

1. Betthauser J, Forsberg E, Augenstein M, Child L, Eilertsen K, Enos J, Forsythe T, Golueke P, Jurgella G, Koppang R, Lesmeister T, Mallon K, Mell G, Misica P, Pace M, Pfister-Genskow M, Strelchenko N, Voelker G, Watt S, Thompson S, Bishop M. Production of cloned pigs from in vitro systems. Nat Biotech 2000; 18: 1055-1059.

2. Onishi A, Iwamoto M, Akita T, Mikawa S, Takeda K, Awata T, Hanada H, Perry ACF. Pig cloning by microinjection of fetal fibroblast nuclei. Science 2000; 289: 11881190.

3. Polejaeva IA, Chen SH, Vaught TD, Page RL, Mullins J, Ball S, Dai Y, Boone J, Walker S, Ayares DL, Colman A, Campbell KHS. Cloned pigs produced by nuclear transfer from adult somatic cells. Nature 2000; 407: 86-90.

4. Bondioli K, Ramsoondar J, Williams B, Costa C, Fodor W. Cloned pigs generated from cultured skin fibroblasts derived from a $\mathrm{H}$-transferase transgenic boar. $\mathrm{Mol}$ Reprod Dev 2001; 60: 189-195

5. Park KW, Cheong HT, Lai L, Im GS, Kuhholzer B, Bonk A, Samuel M, Rieke A, Day BN, Murohy CN, Carter DB, Prather RS. Production of nuclear transfer-derived swine that express the enhanced green fluorescent protein. Anim Biotech 2001; 12: 173181.

6. Park KW, Lai L, Cheong HT, Cabot R, Sun QY, Wu G, Rucker EB, Durtschi D, Bonk A, Samuel M, Rieke A, Day BN, Murphy CN, Carter DB, Prather RS. Mosaic gene expression in nuclear transfer-derived embryos and the production of cloned transgenic pigs from ear-derived fibroblasts. Biol Reprod 2002; 66: 1001-1005.

7. Boquest AC, Grupen CG, Harrison SJ, Mcllfatrick SM, Ashman RJ, d'Apice AJF,
Nottle MB. Production of cloned pigs from cultured fetal fibroblast cells. Biol Reprod 2002; 66: 1283-1287.

8. Dai Y, Vaught TD, Boone J, Chen SH, Phelps CJ, Ball S, Monahan JA, Jobst PM McCreath KJ, Lamborn AE, Cowell-Lucero JL, Wells KD, Colman A, Polejaeva IA, Ayares DL. Targeted disruption of the $\alpha 1,3$-galactosyltransferase gene in cloned pigs. Nat Biotech 2002; 20: 251-255.

9. De Sausa PA, Dobrinsky JR, Zhu J, Archibald AL, Ainslie A, Bosma W, Bowering J Bracken J, Ferrier PM, Fletcher J, Gasparrini B, Harkness L, Johnston P, Ritchie M, Ritchie WA, Travers A, Albertini D, Dinnyes A, King TJ, Wilmut I. Somatic cel nuclear transfer in the pig: control of pronuclear formation and integration with improved methods for activation and maintenance of pregnancy. Biol Reprod 2002; 66 642-650.

10. Lai L, Kolber-Simonds D, Park KW, Cheong HT, Greenstein JL, Im GS, Samuel M, Bonk A, Rieke A, Day BN, Murphy CN, Carter DB, Hawley RJ, Prather RS. Production of $\alpha$-1,3-galactosyltransferase knockout pigs by nuclear transfer cloning. Science 2002; 295: 1089-1092.

11. Lai L, Park KW, Cheong HT, Kuhholzer B, Samuel M, Bonk A, Im GS, Rieke A, Day BN, Murphy CN, Carter DB, Prather RS. Transgenic pig expressing the enhanced green fluorescent protein produced by nuclear transfer using colchicines-treated fibroblasts as donor cells. Mol Reprod Dev 2002; 62: 300-306.

12. Yin XJ, Tani T, Yonemura I, Kawakami M, Miyamoto K, Hasegawa R, Kato $Y$ Tsunoda Y. Production of cloned pigs from adult somatic cells by chemically assisted removal of maternal chromosomes. Biol Reprod 2002; 67: 442-446.

13. Bordignon V, Smith LC. Telophase enucleation: an improved method to prepare recipient cytoplasts for use in bovine nuclear transfer. Mol Reprod Dev 1998; 49: 29-36.

14. Nour MS, Takahashi Y. Preparation of young preactivated oocytes with high enucleation efficiency for bovine nuclear transfer. Theriogenology 1999; 51: 661-666.

15. Dominko T, Chan A, Simerly C, Luetjens CM, Hewitson L, Martinovich C, Schatten G. Dynamic imaging of the metaphase II spindle and maternal chromosomes in bovine oocytes: implications for enucleation efficiency verification, avoidance of parthenogenesis, and successful embryogenesis. Biol Reprod 2000; 62: 150-154.

16. Liu JL, Wang MK, Sun QY, Xu Z, Chen DY. Effect of telophase enucleation on bovine somatic nuclear transfer. Theriogenology 2000; 54: 989-998.

17. Smith LC. Membrane and intracellular effects of ultraviolet irradiation with Hoechs 33342 on bovine secondary oocytes matured in vitro. J Reprod Fertil 1993; 99: 39-44.

18. Tao T, Machaty Z, Abeydeera LR, Day BN, Prather RS. Optimisation of porcine oocyte activation following nuclear transfer. Zygote 2000; 8: 69-77.

19. Kawakami M, Tani T, Yabuuchi A, Kobayashi T, Murakami H, Fujimura T, Kato $Y$, Tsunoda Y. Effect of demecolcine and nocodazole on the efficiency of chemically assisted removal of chromosomes and the developmental potential of nuclear transferred porcine oocytes. Cloning Stem Cells 2003; 5: 379-387.

20. Miyoshi K, Inoue S, Himaki T, Mikawa S, Yoshida M. Birth of cloned miniature pig derived from somatic cell nuclear transferred embryos activated by ultrasound treatment. Mol Reprod Dev 2007; 74: 1568-1574.

21. Wang MK, Liu JL, Li GP, Lian L, Chen DY. Sucrose pretreatment for enucleation: an efficient and nondamage method for removing the spindle of the mouse MII oocyte. Mol Reprod Dev 2001; 58: 432-436.

22. Liu JL, Sung LY, Tian XC, Yang X. Hypertonicity-induced projections reflect cell polarity in mouse metaphase II oocytes: involvement of microtubules, microfilaments, and chromosomes. Biol Reprod 2002; 67: 1853-1863.

23. Liu JL, Sung LY, Barber M, Yang X. Hypertonic medium treatment for localization of nuclear material in bovine metaphase II oocytes. Biol Reprod 2002; 66: 1342-1349.

24. Szell A, Shelton JN. Osmotic and cryoprotective effects of glycerol-sucrose solution on day-3 mouse embryo. J Reprod Fertil 1987; 80: 309-316.

25. Oda K, Gibbons WE, Leibo SP. Osmotic shock of fertilized mouse ova. J Reprod Fertil 1992; 95: 737-747.

26. Saito N, Imai K, Tomizawa $\mathbf{M}$. Effect of sugars-addition on the survival of vitrified bovine blastocysts produced in vitro. Theriogenology 1994; 41: 1053-1060.

27. Otoi T, Yamamoto K, Koyama N, Tachikawa S, Suzuki T. Cryopreservation of mature bovine oocytes by vitrification in straws. Cryobiology 1998; 37: 77-85.

28. Tani T, Shimada H, Kato Y, Tsunoda Y. Demecolcine-assisted enucleation for bovine cloning. Cloning Stem Cells 2006; 8: 61-66.

29. Petters RM, Wells KD. Culture of pig embryos. J Reprod Fertil 1993; 48 (Suppl): 61-73. 